\title{
Application of Augmented Reality for Gypsum Marketing Using Vuforia, Sketchup and Unity 3D
}

\section{Penerapan Augmented Reality Untuk Pemasaran Gypsum Menggunakan Vuforia, Sketchup Dan Unity 3D}

\author{
Ifaldi Danang Septiawan ${ }^{1}$, Cindy Taurusta ${ }^{2}$ \\ \{faldidanang19@gmail.com ${ }^{1}$, cindytaurusta12@gmail.com² ${ }^{2}$.
}

Universitas Muhammadiyah Sidoarjo, Jl. Raya Gelam No. 250 Sidoarjo. 61271 Indonesia ${ }^{1,2}$

\begin{abstract}
The development of technology and information is currently progressing very rapidly, marked by advances in the field of information and technology. One of the most popular technologies today is gadgets. This is revealed by research conducted by Strategy Analytics. The author took the initiative to create an android-based augmented reality technology that is useful for marketing a gypsum product. The method used by researchers is quantitative. The results that have been achieved from this research are adding insight into the latest technology and promotional media.
\end{abstract}

Keywords - Gypsum; Augmented Reality; promotion media

Abstrak. Perkembangan teknologi dan informasi saat ini mengalami kemajuan yang sangat pesat, ditandai dengan kemajuan pada bidang informasi dan teknologi. Salah satu teknologi yang banyak digemari saat ini yaitu gadget. Hal ini diungkap oleh penelitian yang dilakukan oleh Strategy Analytics. Penulis berinisiatif untuk membuat sebuah teknologi augmented reality berbasis android yang berguna untuk pemasaran sebuah produk gypsum. Metode yang digunakan peneliti adalah kuantitatif. Hasil yang telah dicapai dari penelitian ini adalah menambah wawasan tentang teknologi terbaru dan media promosi. Hasil dari penelitian yang didapatkan ialah sebuah aplikasi augmented reality yang dapat memunculkan produk gypsum berupa tampilan objek 3 dimensi virtual. Manfaat penelitian ialah dengan adanya aplikasi augmented reality produk gypsum ini dapat memudahkan produsen untuk mengenalkan produk mereka pada konsumen dan daya tarik pembeli.

Kata Kunci-Gypsum; Augmented Reality; Media promosi

\section{Pendahuluan}

Teknologi antara cetak dengan komputer bisa digabungkan dengan sebuah teknologi augmented reality. [1] Pada dasarnya AR memiliki kelebihan yaitu mampu memberikan pengalaman dan pemahaman yang mendalam bagi user. Ini berarti tidak menutup kemungkinan bahwa teknologi ini dapat dijadikan alat untuk metode promosi yang lebih menarik [2] Penggunaan AR sangat mudah, menarik dan mudah dalam mengerjakan suatu hal, terutama dibagian promosi produk kepada konsumen [3] Kemajuan teknologi mengakibatkan tuntutan masyarakat akan kemudahan, kelengkapan fasilitas, dan kecanggihan dalam segala hal, khususnya pengolahaan informasi, pemilihan terhadap keamanan dan keselamatan bangunan yang akan memberikan rasa aman dan nyaman meningkat [4] pemanfaat teknologi didalam proses penyampaian informasi mengalami perkembangan pesat dalam 2 dimensi maupun 3 dimesni diberbagai bidang seperti pendidikan dan benda benda bersejarah, dll [5] penggunan ponsel atau gadget sangat luar biasa dari $37 \%$ menjadi $35 \%$ pada 2015 di dunia [6]

\section{METODE}

\section{Tahap Pengumpulan Data}

Pada penelitian ini, teknik pengumpulan data yang digunakan oleh peneliti diantaranya membaca buku dan jurnal yang terkait dengan topik penelitian yang diambil, kedua metode pengumpulan data dengan mengisi pertanyaan yang sudah dipersiapkan sebelumnya dan wawancara dengan pakar, ketiga observasi dengan cara mengamati langsung.

\section{Subyek dan Obyek Penelitian}

Dalam penelitian ini subyek yang digunakan adalah pemilik perusahaan dan masyarat umum, sedangkan obyek dari penelitian ini adalah seorang pengembang aplikasi atau development yang mengerti dan memahami dalam hal pembangunan aplikasi. Karena tujuan dan pengguna akhir dari program akan mempengaruhi konsep multimedia yang akan dibuat

\section{Teknik Analisis Masalah}

Masalah augmented reality pada seseorang merupakan dari masalah teknologi dengan menggunakan marker dalam kinerjanya, untuk masalah tersebut diperlukan sebuah pengembang sistem teknologi augmented reality yang mampu 
berperan seperti layaknya seorang ahli dibidanag kemajuan teknologi. Proses analisa identifikasi masalah yaitu tentang informasi dan data yang dibutuhkan [7]

Augmented reality merupakan teknologi baru antarmuka yang berbasis android dan saat ini banyak diterapkan pada berbagai bidang industri dan pemasaran [8].Dalam penerapanya, augmented reality memiliki dua metode yaitu marker based dan markerless based.

\section{a. Marker Based Augmented Reailty}

teknologi augmented reality sebuah teknologi yang menggabungkan benda antara dua dan tiga dimensi kedalam suatu lingkungan nyata [9]. Komputer akan mengenali posisi dan orientasi dari markerdan akanmenciptakan objek virtual yang berupa model atau objek 3 dimensiyaitu padatitik $(0,0,0)$ dan 3 sumbu $(\mathrm{X}, \mathrm{Y}, \mathrm{Z})$.

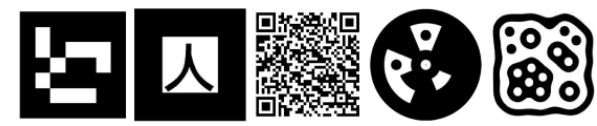

Gambar 2.1 marker based

\section{b. Markerless Augmented Reality Based}

Markerless based augmneted reality adalah metode yang tidak perlu menggunakan sebuah marker untuk menampilkan obyek virtual. Contoh face tracking, 3d object tracking, Mation tracking, gps based tracking.

Vuforia Augmented Reality Software Development Kit (SDK)yang menggunakan teknologi Computer Vision untuk mengenali dan melacak gambar target dan objek 3D secara real time.Vuforia menyediakan Interface Aplication Programing (API)di C++, java, Objective-C, dan bahasa Net. SDK ini memungkinkan pengembangan untuk iOS dan Android dengan mudah.
a. image target
b. vumark
c. Object recognition
d. Cylinder target
e. Muti target
f. User definited target
g. Cloud recognition
h. Native only

Unity3D dapat digunakan untuk membuat sebuag game multi-platform yang bisa diaplikasikan pada perangkat komputer, android, iPhone, PS 3, dan X-BOX.
a. project
b. toolbar
c. scene
d. inspector
e. hierarchy

\section{HaSil Dan Pembahasan}

\section{Perancangan Sistem}

a. flowchart

Flowchart (Diagram Alir) adalah bagan (Chart) yang menunjukan alir (flow) di dalam program atau prosedur sistem secara logika dapat dilihat pada gambar 2. : 
b. Use Case

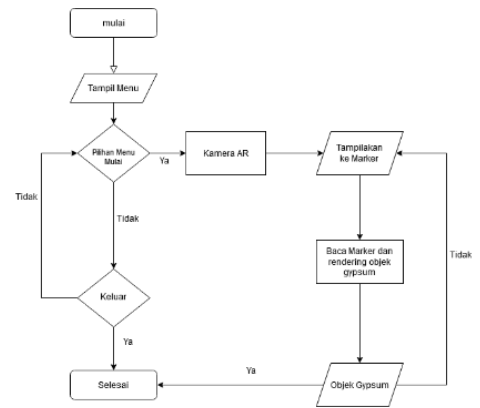

Gambar 2. flowchart

merupakan metodologi dalam pengembangan sistem beroreientasi objek dan alat pendukung [10] dan sebuah teknik yang digunakan dalam pengembangan sebuah software atau sistem informasi untuk menangkap kebutuhan fungsional dari sistem yang bersangkutan.

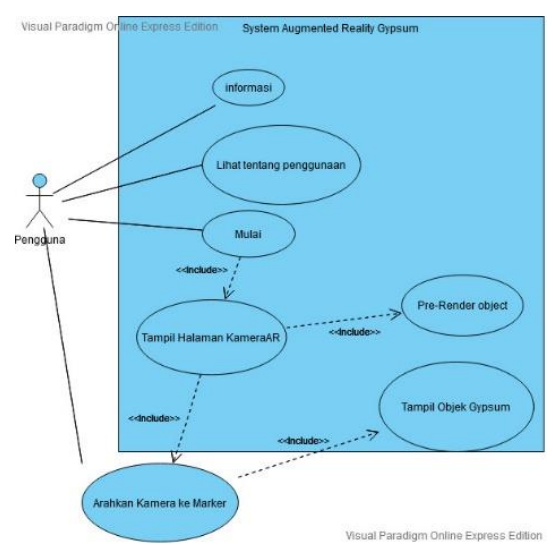

Gambar 3. Use case

\section{Desain User Interface}

1. Scene awal aplikasi

Pada scene ini pengguna untuk memilih kehalaman mana akan pergi.

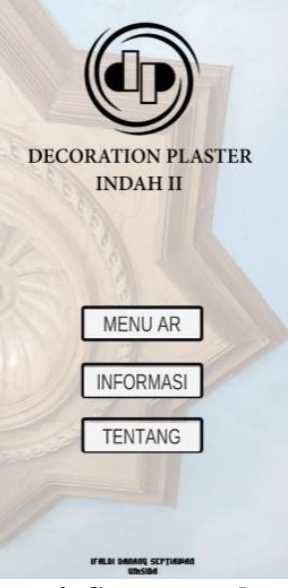

2. Scene Informasi

\section{Gambar 4. Scene awal aplikasi}

Pada scene ini user dijelaskan tentang informasi perusahaan. 


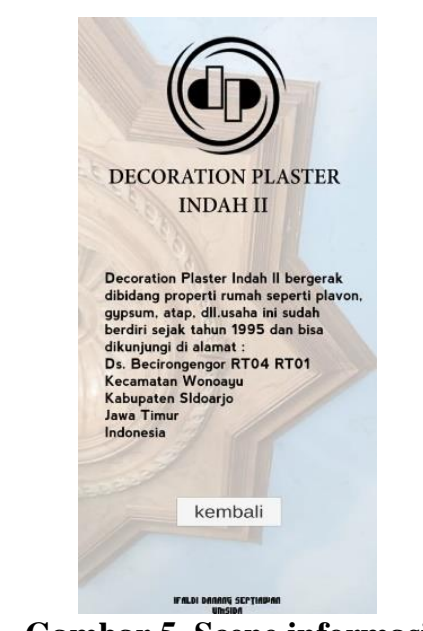

3. Scene tentang

Pada scene ini user diperlihatkan tentang pembuat aplikasi atau development.

4. scene AR

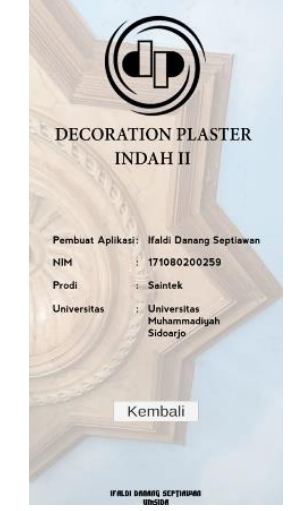

Merupakan scene yang menscan marker yang akan muncul sebuah model 3d.

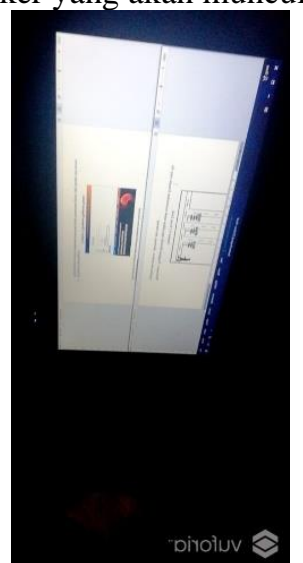

Gambar 7. Scene AR

\section{KESIMPULAN}

Dari hasil penilitan ini teknologi augmented reality bisa menjadi opsi untuk pemasaran sebuah produk agar menjamin konsumen dari tingkat keraguan memilih sebuah produk. Media promosi berbasis teknologi bisa menciptakan hal yang bagus karena tingkat peminatan produk terhadap teknologi sangat cocok dikembangkan.

\section{Ucapan Terima Kasih}

Dengan penelitian ini, penulis mengucapkan terimakasih banyak kepada semua pihak terkait yang sudah memb antu dalam melakukan penulisan artikel ilmiah yang berjudul "Penerapan augmented reality untuk pemasaran gypsum menggunakan vuforia, sketchup dan unity3d". 


\section{REFERENCES}

[1] A. C. Jayang Nurdiansyah, "Journal of Information Technology and Computer Science (JOINTECS)," Augmented Reality Untuk Media Promosi Rumah Pada Alang-Alang Contruction Berbasis Android, vol. III, no. 3, p. 243, 2018.

[2] K. I. S. K. T. M. Alan Zuniargo Prabowo, Perancangan implementasi augmented reality sebagai media promosi penjualan perumahan, vol. III, no. 1, p. 161, 2015.

[3] T. L. A. L. Muhammad Rifa'i, "Prosiding SNATIF," Penerapan teknologi augmented reality pada aplikasi katalog rumah berbasis android, p. 267, 2014.

[4] I. S. A. R. W. Zahir Zainuddin, "JNTETI," Aplikasi Augmented Reality pada sistem informasi smart building, vol. V, no. 3, p. 207, 2016.

[5] p. haryani, "jurnal simetris," augmented reality sebagai teknologi interaktif dalam pengenalan benda cagar budaya kepada masyarakat, vol. VIII, no. 2, p. 807, 2017.

[6] a. t. ,. m. i. fahdian rahmandani, "jurnal civic hukum," analisis dampak penggunaan gadget (smartphone) terhadap kepribadian dan karakter (kekar) peserta didik di SMA negri 9 malang, vol. III, no. 1, p. 19, 2018.

[7] r. w. e. a. setyawan, implementasi augmented reality sebagai media pemasaran berbasis android pada brosur handphone, p. 6.

[8] s. r. b. s. muhammad riadi alamsyariqi, "seminar nasional aplikasi teknologi informasi (SNATi)," rancangan bangun aplikasi augmented reality untuk virtual fitting room frame kacamata, p. 86, 2018.

[9] r. r. i. k. t. m. rachel chrysilla tijono, "jurnal teknologi dan sistem komputer," penerapan teknologi augmented reality sebagai sarana promosi produk" sarana sejahtera wilson's office chairs' berbasis android, vol. III, no. 4, p. 494, 2015.

[10] a. hendini, "jurnal khatulistiwa informatika," permodelan uml sistem informasi monitoring penjualan dan stok barang (studi kasus : distro zhezha pontianak), vol. IV, no. 2, p. 108, 2016. 